\title{
Evidence of Trade Union Membership and Expectations at a Scottish University
}

\author{
Dr. Theresa Marie Majeed \\ Assistant Professor \\ College of Business \\ Hawai'i Pacific University \\ Honolulu, Hawai'i, United States \\ E-mail: tmajeed@hpu.edu \\ USA
}

\section{ABSTRACT}

This work presents insights on trade union member employees' expectations of union membership and its association with their perceptions of job dissatisfaction at a Scottish university. For over five decades, employees in trade unions have reported higher levels of dissatisfaction with their jobs than non-unionized employees in studies from different countries. The question of trade union membership and job dissatisfaction remains open to inquiry because previous studies used quantitative analyses, yet industrial relations scholars still do not possess a salient explanation for why the phenomenon exists. In contrast to those studies, this work used a qualitative approach of 23 interviews with trade union member employees. The results of the present work contribute to an area in need of data, as the expectations of trade union membership presented here were gathered from a diverse group of trade union member employees to which contemporary trade unions are focusing their recruitment efforts.

\section{Keywords: Trade unions; employee relations; university restructuring; union representation}

\section{Introduction}

The present paper reports the results of the data analysis of trade union members' dissatisfaction related to their unmet expectations of union membership. It is part of a wider study of trade union membership and job dissatisfaction or an issue derived from more than five decades of research that shows us trade union member employees report greater dissatisfaction with their jobs than non-union members. Evidence of this can be found in works across different countries by authors such as Freeman,1978; Borjas,1979; Freeman, 1980; Odewahn and Petty, 1980; Berger et al; Freeman and Medoff, 1984; Schwochau, 1987; Hersch and Stone,1990; Meng,1990; Miller,1990; Lincoln and Booth,1993; Clark,1996; Bender and Sloane, 1998; Heywood et al, 2002; Renaud, 2002; Guest and Conway, 2004; Bryson et al, 2004; Jones and Sloane, 2009; Krieg et al, 2013; Green and Heywood, 2015; Haile,2015; Laroche, 2016; and Laroche,2017. Trade union member employees' dissatisfaction persists, even though trade unions are widely known to improve terms and conditions of employment (Nickell, 1977; Freeman and Medoff, 1984; Jarrell and Stanley, 1990; Booth, 1995; Miller and Mulvey, 1996; Delery et al, 2000; Arabsheibani and Marin, 2001; Blanchflower and Bryson, 2004; Hirsch, 2004; Pencavel,2009; West and Mykerezi, 2011; Long, 2013; RiosAvila and Hirsch, 2014; Torm,2014; and Bryson and White, 2016).

\section{Literature Review}

The concept of unmet expectations has its basis in the association between unionized employees' job dissatisfaction and the notion that trade unions may not perform according to their members' expectations. Guest and Conway (2004) suggest that employees in trade unions report job dissatisfaction when their trade unions do not perform according to the reasons those employees had for joining a trade union in the first place. The previous authors indicate that employees join trade unions for instrumental reasons and when trade unions do not provide the benefits those employees expected to receive through union membership; they may become less loyal to their trade union(s) (ibid). Hammer and Avgar (2005:243) indicated that trade union members' express job dissatisfaction that is related to their trade unions raising their memberships' expectations to levels that are 'beyond what is realistic'. In the present paper, the term 'unmet expectations' is used to connote the loosely constructed idea that trade union members believe there are benefits to joining a trade union and express dissatisfaction with their jobs when those benefits go unrealized. In the present work, the dimensions which underscore that idea include insights derived directly from trade union members themselves. 


\section{International Journal of Business and Applied Social Science}

E-ISSN: 2469-6501

VOL: 6, ISSUE: 3

March/2020

DOI:10.33642/ijbass.v6n3p7

https://ijbassnet.com/

Next, it is important to clarify that trade unions are generally known to act on behalf of, and to protect the interests of, their members (van den Berg and Groot; 1992; Sverke and Goslinga, 2003; Simms and Charlwood, 2010; Stinglhamber et al, 2013). As such, any prior research that suggests trade union members have expectations from trade union membership is not especially surprising. What those expectations are, however, is another story altogether. This is large because, as a more recent article suggests, the purpose of trade unions in contemporary society is being reinvented as trade unions use different strategies towards union revitalization that acknowledge more diverse potential membership bases (Hodder and Edwards,2015). The previous strategy has been described as attempts by trade unions to"organize diversity", which includes trade union organizing activities focused on recruiting women, minorities, migrant employees, and individuals in precarious work (Heery, 2015:546). The present work contributes insights to at least two areas within the field of industrial relations, then, as it enables a better understanding of expectations of trade union membership as developed from the perspectives of a diverse group of interviewees at a university during a restructuring.

\section{Methodology}

The present study used a qualitative approach that included identifying salient themes associated with the research phenomenon from the responses of trade union member employees themselves. It is possible to capture authentic and personalized contexts using interviews (Miles et al, 2014), embedded as they are in processes within which interpretation and subjective meaning are interwoven (Denzin,1998). A case study approach was used, as these allow researchers to capture insights on phenomena that are inseparable from the contexts in which they are associated (Yin,2014). Interviews were appropriate for exploring and adding insights towards understanding the research phenomenon in the present work, as they enable individuals to voice their perspectives (Kvale,1996). Unscripted and intensive interviews were also critical to developing themes in the present research, as these enable researchers to explore emergent topics with interviews in greater detail (Charmaz,2014). The questions used in the present research were largely unscripted, although three interview questions were asked of each interviewee including why they had joined their trade union, what they expected in return for joining their union, and whether or not their union had met their expectations. Furthermore, those three questions were used because they highlight the theoretical underpinnings on trade union membership and unmet expectations rest. Furthermore, the number of interviews in the present study (23) was sufficient for purposes of this study, as Creswell (2013) recommends interviewing from 20 to 30 individuals in-depth to capture insights. It is important to acknowledge that Majeed (2020) includes a description of the methodology used in the present study as well, given that it is the first work to be disseminated about the university portion of the overall project within which this paper is a part.

The present study includes a case study organization located in a city in Scotland that was, before the Thatcher era, known as a manufacturing hub of powerful trade unions and militant trade unionist activity. Most manufacturers have closed since then and the present case study organization a university was one of the few remaining major employers in the city at the time interviews were conducted. Fieldwork for the present research was conducted in 2015, following the Scottish Referendum vote of September 14, 2014. The wider context is important to clarify, given that the majority of the city's voters had voted in favor of Scottish independence. There was, undoubtedly, lingering resentment and tensions in the city from those who had wanted Scotland to have its independence towards those who had voted to remain.

The university system in the United Kingdom was also changing, given that the government had implemented a system beginning in the 1980s now known as the Research Excellence Framework by which government funding granted to institutions of higher education was done through rating the quality of the publications of academics at a given institution. The better the ratings, the more funding institutions received so that academic faculty in the United Kingdom, in general, was widely understood to have increasing pressure related to job insecurity. Unbeknownst to the researcher until the time when the first interview was conducted, the present case study organization was in the process of a restructuring that was part of the Principal and Vice Chancellors (the same individual) initiative to increase the university's rankings. As part of the restructuring, the performance of employees across the case study organization was being reviewed and many individuals had already been made redundant, while many of those that remained were uncertain about their job security.

There were a total of 23 interviewees from different physical locations and divisions at the university, and in different roles. Three trade unions were present at the time fieldwork was conducted include i) the Red trade union represented the 
academic faculty; ii) the Green trade union represented technical employees, and iii) the Blue trade union represented administrative and clerical staff. The three trade unions were not treated separately in the present study, given that a common theme was sought with the research phenomenon. The diverse mix of interviewees included in the present study is shown in Table 1 below.

Table 1: Description of Interviewees

\begin{tabular}{|c|c|c|}
\hline Interviewee & Age, Job Title, Gender, Tenure & Trade Union \\
\hline D1 & 58, Female, Lecturer, 25 years. & Red \\
\hline D2 & 65, Professor, Male, 4 years and 4 months. & Red \\
\hline D3 & 45, Female, Student Funding Officer, 17 years. & Red \\
\hline D4 & , Male, Lecturer, 21 years. & Red \\
\hline D5 & 31, Male, Lecturer, 1 year. & Red \\
\hline D6 & 56, Male, Technician, 26 years. & Green \\
\hline D7 & 47, Male, Library Assistant, 13 years. & Blue \\
\hline D8 & 57, Female, Lecturer, 5 years and 6 months. & Red \\
\hline D9 & 34, Female, Lecturer, 2 years and 6 months. & Red \\
\hline D10 & 48, Male, Security, 8 years. & Blue \\
\hline D11 & 60, Male, Security, 27 years. & Blue \\
\hline D12 & 30, Female, Finance Officer, 14 years. & Blue \\
\hline D13 & 58, Female, Undergraduate Administrator, 36 years. & Blue \\
\hline D14 & 26, Male, International Business Development, 5 years. & Blue \\
\hline D15 & 56, Female, Student Coursework Administrator, 15 years. & Blue \\
\hline D16 & 53, Female, Lecturer, 12 years. & Red \\
\hline D17 & 40, Female, Administrative Support, 6 years. & Blue \\
\hline D18 & 30, Female, Finance Officer, 2 years. & Blue \\
\hline D19 & 53, Female, Finance Administrator, 11 years. & Blue \\
\hline D20 & 56, Male, IT, 34 years. & Green \\
\hline $\mathrm{D} 21$ & 57, Male, IT, 17 years. & Green \\
\hline $\mathrm{D} 22$ & 66, Male, Academic Department Chair, 3 years. & Red \\
\hline D23 & 45, Male, IT, 13 years. & Green \\
\hline
\end{tabular}

\section{Results}

The results show that some trade union members had low expectations of their trade union in the first instance and/or expressed disappointment related to trade union weakness. Some interviewees alluded to the restructuring that was taking place at the university and expressed frustrations related to their trade union's responsiveness, or lack thereof, to changes. Responses from trade union members included beliefs that their respective trade union(s) did not have adequate resources to address their members' issues. Furthermore, some trade union members suggested that their trade union had prioritized the issues of some members over the issues of other members, even though the other members they described were not members of their trade union. There were also trade union members that expressed dissatisfaction with their trade union's representatives.

Responses from D10, who worked in security and had 14 years of experience, replied whether the trade union had lived up to his expectations with the following statements:

'Um...yes and no. Um, I mean you've got quite good conditions, ah, which is probably been a mixture of the university and the trade union, ah, throughout the years trying to, ah, ah, get things. Ah, and then I think it all depends...Yeah, um. I think also it just depends um...on ah, who you've got as shop steward as well. Um, I know, ah...as far as ah, they can...um, speak on behalf of the members. Um, I know, so, I think it, a big thing is ah, who the shop steward [is]'. 
D10 seemed largely dissatisfied with the trade union's shop steward, who had not met regularly with his department:

'Um, I think since I've started here at the university...I think they've had one union meeting, and that was when the janitors and the security were amalgamating. Um, and, I was on holiday then. Um, so in eight years, I've never had a union meeting... Um, but that, on um...the union front at the university, I'm a wee bit disappointed, ah, that they don't have um...more union...meetings. Ah, but again, that's probably nothing to do with...the university side. That's probably more to do with...your full-time official and shop steward at the university. Ah, they should be, ah, having meetings. Um, and just sort a...you know, little things can build up in a workplace. Um, and I've seen that before. And there, they're probably very little things. But, if you...let...every little thing build-up, it can come to a head...and explode. Um, so I always think it's better to um, keep the air a bit clearer I know and things, on that side, it could probably do a bit better'.

The responses above from D10 suggest that trade union member's insecurity had not been consulted by the trade union regarding changes to their jobs. As D10 reported, the original terms of his position included working night shifts, which he 'enjoyed'. After the amalgamation, however, he had to work the day shift:

'Um, well what it was um...what's changed in my job is, as I say, we were ah, permanent night shift, ah, security, and the security and the janitors...amalgamated. Um, and...I was hoping, you know, they might have said, you know, keep the janitors on...day ah, like an early shift and, which they were used to. And, we were going to stay on the night shift, but that never, ah, happened. Everyone, ah, got amalgamated together and um...the shifts changed...without really...much notice. Um, there was, ah, extra money involved...for the people that were coming off day shift. So I can see, um...their incentive. I know it was a lot more money. Um, for the night shift workers then, I know we never really...benefitted. But we had to come on day shift...um, as well as doing the night shift. Ah, where, ah, when I first started at the university, I applied for a job, it was the permanent night shift. Um, which I enjoyed, and you got in a slight routine'.

It seemed that perhaps the trade union had not met D10's expectations because it had not enabled its members in security to have a voice in decisions that affected them:

'Um, but, um...people don't like change. Um, but I think that sometimes it'd be better going to um...the people that do the jobs and ask them...what their um, opinion on the matters would be. Where sometimes, um, things are just changed without um...asking people that do the job'.

Trade union member D11 was also employed in security and he expressed dissatisfaction with the trade union because it had not kept him informed. He had expected the trade union to keep him informed and emphasized that he paid the trade union to do so:

'So, and then sometimes you wonder if their...they, they, the union sometimes know things that they haven't told us. And like the management says well we don't want this to be known until this thing happens, and I've heard these things...these things happening, or maybe, like, changes that's going on. And I think to myself, well obviously, I'm paying my union dues to be informed...not to have things kept from me, but. That's just, that's just a bugbear at the moment'.

D11 was 60-years old and had worked at the university for 27 years. He indicated that he was generally dissatisfied with the trade union and indicated that the trade union had not protected the interests of the lowest-paid workers. He indicated the trade union had planned a day of action which might have benefitted the academic staff, yet hurt the university's cleaning staff:

'You're supposed to have solidarity with...the um...lecturers I think. They just take a holiday...so they don't lose any money. So the only people that are suffering is anybody...takes a day off, like cleaners or security or something like that, or who cross the picket line. They lose money'.

Blue trade union member D15 was an administrator with 15 years of experience and her reply to why she had joined the trade union emphasized the protection it provided: 


\section{International Journal of Business and Applied Social Science}

E-ISSN: 2469-6501

VOL: 6, ISSUE: 3

March/2020

DOI:10.33642/ijbass.v6n3p7

https://ijbassnet.com/

'Ah, I joined initially because I could see some problems happening in my work environment. And that was why I joined, I joined for some...protection that I may need in the future. And I, I joined as a backup...for a potential problem'.

In response to the question of whether the trade union had lived up to her expectations, D15 stated: 'No, not always, I have to say. This is confidential, isn't it?'. The researcher assured her it was and her responses, like those of D10, highlighted that trade union representatives themselves could impact on how interviewees experienced dissatisfaction related to unmet expectations:

'Not always, no, no. It hasn't. I had a situation, about three years ago...where I had, new management came in. And it was very suppressing. Very bullying. Ah, and I, I went off... with stress. And, while I was off, I was in the union at this point. Um, I did have a student, I had to tell the union rep helping me, and initially, I thought...this is good, this is good help. But it didn't...it, they...I didn't feel that the union rep did her job properly. So that was a...that wasn't, that wasn't good. And, I managed to get back to work; I was off for eight months. Um, so...yeah, I can say that it depends on who your rep is'.

Furthermore, D10 described a university staff survey in which her department 'came out as the worst for the bullying'. D6 was a 56-year old senior technician and trade union representative with 26 years of experience. He described trade union protection from his point of view as a trade union caseworker:

'There are times when I have to represent people, and I don't feel...I want to do it on a personal level because I feel they are wrong. I sometimes feel that to represent person A, I might be compromising person B, who might be completely innocent. So, it's a, it's a, it can be a moral dilemma because I'm obliged to represent every single person who is a member of the union who comes to me for representation. However, how I represent them...is largely down to my experience and judgment. So, I can try to channel them into a course of action that is less confrontational, and that's what I try to do. If I genuinely think, I, I...how do I put this. I don't represent people in the way that they want to be represented. I represent them in what I believe to be in their best interest. And it maybe if someone's simply being foolish, or simply misunderstanding a situation, the best thing I can do is to tell them to grow up and let the matter drop. And that can be difficult for them to hear. But it's better coming from me than from their department or their manager, where it might then compromise their future career. So that's a difficult conversation, and I, I have that regularly. I think, to me the outcome is what's important. And the outcome is to protect the individual. And if you have to tell them something, a harsh truth to do that, then that, that's simply something that has to be done'.

The following responses were from trade union member D9, a 34-year old lecturer from India; highlight dissatisfaction with the academic trade union because it had not addressed all of its members' issues. Furthermore, D9 expressed disappointment with the trade union for being weak, as the trade union did not have enough members:

'No. Um, the reason I'm not satisfied with the trade union's performance is unfortunately I think they're fighting too many battles. And they can't. They don't have the membership, not...I think, maybe a quarter of staff or maybe even less than that...are, um, is a member of the trade union, a member of the trade union. So they have a very small pool to work with anyway. Um, and they have just too many battles to fight'.

D9 also suggested that the management had tried to close the political science department in which she was a lecturer. She and other trade union members in her department had sought protection from the trade union against their Dean. D9 and her colleagues had suffered mentally and emotionally, and she expressed dissatisfaction with the trade union for not having acknowledged the situation. Yet, D9 also indicated that the trade union had many 'battle(s) to fight', which suggests that circumstances were likely dire for academics in general at the university:

'Our acting Dean would basically call us for a meeting and not tell us what the meeting was about. Uh, almost, uh...send us an ultimatum, um, not an ultimatum but a decree...that's when the meeting is happening. And, not knowing what it is about, you have to attend because you don't know what it's about. Whether there is something minor or something that's potentially...might change the way you do your job. So, um, that kind of uncertainty, that kind of, you 


\section{International Journal of Business and Applied Social Science}

E-ISSN: 2469-6501

VOL: 6, ISSUE: 3

March/2020

DOI:10.33642/ijbass.v6n3p7

https://ijbassnet.com/

know, ruling with an iron fist and....oh, it was a very, very difficult, um...few months, um. I certainly...ended up...um, having to seek counseling...um, during that, during that period. My, I know at least one colleague also had to seek counseling for, you know, it, the level of stress was just...unprecedented. F-for me, I've been an academic now for four and a half years, and I've never had a situation where I've been...so bad, where I've had to seek counseling. And just completely work-related stress. And there's no acknowledgement of this, um, by the university...certainly. Um, I think the union is fighting too many battles to acknowledge this. Um, they know...I mean, obviously members know on an individual level, but there's too many things that are going wrong, for the uni, for the union to be able to say right, that's another battle we need to fight'.

D9 repeatedly suggested that the trade union had not acknowledged her or its members' issues, at least 'not officially'. This might have been due to the trade union's lack of resources to address all of its members' issues, as 'so much' had 'happened all over':

'And there's a lot of things that have happened at (university named) in the last year, ah, with redundancies, with, um...ah, what is the word...um, voluntary severance. Um, and not just the fact that these have been introduced, but the way in which they have been introduced. So a lot of bullying. Um...um, that's not been acknowledged at all. Not even by the trade union, actually. Um, or if it's been acknowledged by the trade union, it's, it's been acknowledged by members, not officially. Um, so it, that's just the tip of the iceberg, I mean there's so much that's happened all over'.

Another trade union member, D14, was a 26-year old from Pakistan who worked in the international office. His reply as to why he had joined the trade union suggested that his expectations were low: 'So, I mean, I didn't really have any expectations, I mean, like obviously worse-case scenario you have that kind of safety net'.

In response to being asked to provide more details related to his expectations, D14 communicated his belief that the trade union was weak and expressed disappointment with the trade union's circumstances. His descriptions of the trade union seemed to highlight his low expectations, as he did not believe that the trade union had the support of its members:

'And, I think, like a trade union is as strong as its membership. Ah, and, like I think...we've struggled, like people have dropped out, some of them have come back. And, I think what...they've noticed is that...when things go wrong, and there's a sudden spike in membership. So suddenly, you know, people are joining in from that particular department, if there's...a talk going on for them. Then, when things calm down, people just...you know, kind of discontinue that'.

The next two trade union members, D20 and D23, were technical staff employees. Their department was the main target for voluntary redundancies at the university and they had recently experienced a major restructuring. All of the technical employees' jobs were made obsolete and each technical employee had to reapply for new jobs within the department. Some employees, such as D20 and D23, had been able to get better positions.

Trade union member D20 had worked at the university for 34 years and was close to retirement. He was dissatisfied with the trade union because he believed that the trade union prioritized the academic staff's issues over the issues of the technical staff. Yet, D20 was a member of the trade union that generally represented trade union members in technical roles:

'But I do kind a feel that the union has been more focused on academic wrong...so, a, I will still...still remain a member of the union, but um...I, I didn't think that, I thought they could have been more proactive in some of the things that, that were going on'.

D20 indicated that the restructuring had negative effects on his mental health and that of the technical staff in general. It also became clear in the latter part of his responses that he was considering contacting the trade union's health and safety representatives, perhaps for representation, to confront the university regarding 'what they did'. This is shown in his responses below:

'But it did seem very unnecessary and brutal, there are a lot of people now on medication. Ah, I nearly went, I, I, I got in the car one day and drove three hundred miles. Ah, and, and so the rest of me got sick, just because the pressure all became too much. Um, that was just at the time when we had to apply, finally apply for the, the final tranche of jobs, I just couldn't cope any more. Um...we've sat with colleagues in tears...oh, loss of sleep, um, irritability, um...I'd say I 


\section{International Journal of Business and Applied Social Science}

E-ISSN: 2469-6501

VOL: 6, ISSUE: 3

March/2020

DOI:10.33642/fjbass.v6n3p7

https://ijbassnet.com/

just...went mental one day and...Just got, threw lot stuff in the car, and took my passport and...Was not going to come back. Um, it a...yeah, the pressure has been intolerable. It's been for eight months, and um, I'm, I started doing a wee bit of digging, stuff here, not sure where it is. Um, there seems to be a huge, huge body of psychological research which says that um...job uncertainty of that kind of level, or that kind of the same time period, will make you sick. Um, and will have quite detrimental effects. And I am seeing that, I mean I know people are on medication and they're, people have been very, very stressed and ah, lost sleep and...it was just, it was just uncertainty. Um, so I think a...I think something needs to be done about that. That they should never be allowed to get away with that again. Um, and I've not yet had my return to work meeting from the time when I had my week off sick. And I'm going to insist that that happens. And I'm going to, to insist that um...maybe somebody from a, um...health and safety's there. Ah, and the university's made to look at what they did. And a, I don't think it's acceptable, um, what they did to this place'.

D23 was a 45-year old male technical services manager who had joined the trade union for protection: 'No, no benefits, just...being part of an organization that stands up for everybody else in the university, whether they're union members or not'. For clarity, it is important to mention that whilst D23 perceived the trade union as 'an organization' that protected 'everybody', the trade union representatives did not provide trade union representation to non-union members.

Although D23 applied for a job within his department's new structure and had been advanced, he expressed disappointment with the trade union:

'I feel they treat professional services slightly less...compared to academics. I feel that, because they're on the...union committee. There aren't that many professional service representatives. So that feels as though well, it's not really as important. Purely my opinion, we're not as important as academics. Within the organization, and the union, that's just my feeling. Feels like...every time we raise an issue, it's not taken as serious as...issues that are raised from...fellow union members in Schools. I don't know why that is. It's, it's how it feels'.

Like D20, D23 suggested that the trade union supported academics more so than technical staff, even though he was a member of the trade union known to represent the interests of technical trade union members.

\section{Discussion}

The prior section included the main topics that emerged in exploring trade union members' unmet expectations with their trade union at a university in Scotland. The results suggested that some trade union members had low expectations of their trade union in the first instance and/or believed that their trade union was becoming weaker over time. Some trade union members alluded to organizational changes that were taking place at the university and it seemed that their perceptions surrounding these changes might have negatively impacted their expectations. Responses from trade union members in the Green, Blue and Red trade unions included beliefs that the trade unions did not have the resources to address all of their members' issues. Some trade union members, moreover, suggested that their trade union had prioritized the issues of some of its members over the issues of its other members, even though the other members were not represented by their trade union.

There were also trade union members that expressed dissatisfaction with their trade union's representatives. From the responses of trade union representative D6, it also seemed possible that some trade union representatives might have had the autonomy to decide who to represent and how to represent them. Yet, decisions related to representation also included elements of protection by trade union representatives that might not have been perceived as such by trade union members themselves. It is also possible that two issues the trade unions' lack of resources and the trade union representative's autonomy over critical issues regarding representation were linked. For example, maybe the number of trade union representatives at the university was not enough to manage the issues of all trade union member employees seeking assistance from their union so that perhaps representatives such as D6 had to limit the number of members they represented out of necessity.

The idea that the trade unions at the university had focused on the issues of some of their members over other members emerged repeatedly in interviews. For example, it was suggested that the Blue trade union had prioritized the issues of its academic members over the issues of its lowest-paid members. Yet, the Blue trade union was generally known to represent trade union members in clerical and manual roles. Other perceptions were that the Green trade union had prioritized the issues of its academic members whilst its technical members suffered through a painful restructuring. However, the Green trade 


\section{International Journal of Business and Applied Social Science}

E-ISSN: 2469-6501

VOL: 6, ISSUE: 3

March/2020

DOI:10.33642/fjbass.v6n3p7

https://ijbassnet.com/

\section{Center for Promoting Education and Research (CPER) USA}

WWW.cpernet.org

union was generally known to represent the interests of trade union members in technical roles. Responses such as these seemed to highlight that the Green and Blue trade union members might have been confused about the ability or inability of their respective trade unions to influence decisions made by other trade unions. However, it also seems likely that those interviewees were accustomed to the Green, Blue, and Red trade unions working, at least to some extent, cooperatively with each other during dire circumstances. The previous idea seems supported by reports from trade union representatives themselves, which are not referenced in this paper, but was made when the researcher was establishing site access. Initial discussions during the time in which access to the site was being negotiated highlighted largely adversarial relations between the trade unions and management at the university in which the three respective trade unions were acting to resolve similar issues on behalf of their members with the restructuring. This also seems likely when shown in the light of what is generally understood about the processes that underscore trade union activity, collective representation, and collective bargaining.

\section{Conclusion}

Despite all of the insights presented in this work, it must be acknowledged that it did not capture the perceptions of senior management at the university. It could very well have been the case that senior leadership had a strong and potentially beneficial rationale for conducting a restructuring. Even though public news reports beginning in 2018 revealed issues related to the potential misconduct of senior leadership at the university that included but was not limited to bullying, this information does not reveal much about the decision-making processes that underscored the restructuring proper. While news reports seem to support the responses of many interviewees in the present work, understanding the processes that underscore managerial decision making in unionized workplaces during times of restructure remains open to further understanding. Research into the latter area would help to bridge the gap between the information or lack thereof provided by trade unions to their members during restructurings and the actual decision-making processes of senior management that lead to restructurings in the first place. It could very well be the case that leadership would present an entirely different narrative that helps to expand on what is understood about trade union members and their perceptions.

\section{References}

Arabsheibani, G.R. and Marin, A. (2001). 'Union membership and the union wage gap in the U.K.', Labour, Vol. 15, No. 2, 221-236.

Bender, K.A. and Sloane, P.J. (1998). 'Job satisfaction, trade unions, and exit-voice revisited', Industrial and Labor Relations Review, Vol. 51, No. 2, 222-240.

Berger, C.J., Olson, C.A. and Boudreau, J.W. (1983). 'Effects of unions on job satisfaction: the role of work-related values and perceived rewards', Organizational Behavior and Human Performance, Vol. 32, 289-324.

Blanchflower, D.G. and Bryson, A. (2004). 'What effect do unions have on wages now and would Freeman and Medoff be surprised?', Journal of Labor Research, Vol. 25, No. 3, 383-418.

Borjas, G.J. (1979). 'Job satisfaction, wages, and unions', Journal of Human Resources, Vol. 14, No. 1, 21-40.

Booth, A.L. (1995). The economics of the trade union, Cambridge University Press, Cambridge.

Bryson, A., Cappellari, L., and Lucifora, C. (2004). 'Does union membership really reduce job satisfaction?', British Journal of Industrial Relations, Vol. 42, No. 3, 439-459.

Bryson, A. and White, M. (2016). 'Unions and the economic basis of attitudes', Industrial Relations Journal, Vol. 47, No. 4, 360-378.

Charmaz, K. (2014). Constructing grounded theory, $2^{\text {nd }}$ Ed, SAGE Publications Ltd., London, Thousand Oaks, C.A. Clark, A.E. (1996). 'Job satisfaction in Britain', British Journal of Industrial Relations, Vol. 34, No. 2, 189-217.

Creswell, J.W. (2013). Qualitative inquiry \& research design: choosing among five approaches, 3rd ed., Sage Publications, Inc., Thousand Oaks, California. 
Delery, J.E., Gupta, N., Shaw, J.D., Jenkins, Jr., G.D, and Ganster, M.L. (2000). 'Unionization, compensation, and voice effects on quits and retention', Industrial Relations, Vol. 39, No. 4, 625-645.

Denzin, N.K. (1998). 'The art and politics of interpretation' in Collecting and Interpreting Qualitative Materials, 313-344, Eds. Denzin, N.K. and Lincoln, Y.S. Sage Publications, Inc. Thousand Oaks, California.

Freeman, R.B. (1978). 'Job satisfaction as an economic variable'. American Economic Review, Vol. 68, No. 2, $135-141$.

Freeman, R.B. (1980). 'The exit-voice tradeoff in the labor market: unionism, job tenure, quits, and separations', Quarterly Journal of Economics, Vol. 94, Vol. 4, 643-673.

Freeman, R.B. and Medoff, J.L. (1984). What do unions do? Basic Books, Inc., New York, N.Y.

Green, F. and Heywood, J.S. (2015). 'Dissatisfied union workers: sorting revisited', British Journal of Industrial Relations, Vol. 53, No. 3, 580-600.

Guest, D.A. and Conway, N. (2004). 'Exploring the paradox of unionized worker satisfaction', Industrial Relations Journal, Vol. 35, No. 2, 102-121.

Haile, G.A. (2015). 'Workplace job satisfaction in Britain: evidence from linked employer-employee data', Labour, Vol. 29, No. 3, 225-242.

Hammer, T.H. and Avgar, A. (2005). 'The impact of unions on job satisfaction, organizational commitment, and turnover'. Journal of Labor Research, Vol. 26, No. 2, 241-266.

Heery, E. (2015). 'Unions and the organizing turn: reflections after 20 years of organizing works', The Economic and Labour Relations Review, Vol. 26, No. 4, 545-560.

Hersch, J. and Stone, J.A. (1990). 'Is union job dissatisfaction real?', Journal of Human Resources, Vol. 25, No. 4, 736-751.

Heywood, J.S., Siebert, W.S., and Xiangdong, W. (2002). 'Worker sorting and job satisfaction: the case of union and government jobs', Industrial and Labor Relations Review, Vol. 55, No. 4, 595-609.

Hirsch, B.T. (2004). 'Reconsidering union wage effects: surveying new evidence on an old topic', Journal of Labor Research, Vol. 25, No. 2, 233-266.

Hodder, A. and Edwards, P. (2015). 'The essence of trade unions: understanding identity, ideology and purpose', Work, Employment and Society, Vol. 29, No. 5, 843-854.

Jarell, S.B. and Stanley, T.D. (1990). 'A meta-analysis of the union-nonunion wage gap', Industrial and Labor Relations Review, Vol. 44, No. 1, 54-67.

Jones, R.J. and Sloane, P.J. (2009). 'Regional differences in job satisfaction', Applied Economics, Vol. 41, 1019-1041.

Krieg, J.M., Wassell, Jr., C.S., Hedrick, D.W. and Henson, S.E. (2013). 'Collective bargaining and faculty job satisfaction', Industrial Relations, Vol. 52, No. 3, 619-644.

Kvale, S. (1996). Interviews: an introduction to qualitative research interviewing, Sage Publications, Inc. Thousand Oaks, California.

Laroche, P. (2016). 'A meta-analysis of the union-job satisfaction relationship', British Journal of Industrial Relations, Vol. 54, No. 4, 709-741.

Laroche, P. (2017). 'Union membership and job satisfaction: initial evidence from French linked employer-employee data', Human Resources Management Journal, Vol. 27, No. 4, 648-668.

Lincoln, J.R. and Boothe, J.N. (1993). 'Unions and work attitudes in the United States and Japan', Industrial Relations, Vol. 32, No. 2, 159-187.

Long, G.I. (2013). 'Differences between union and nonunion compensation, 2001-2011', Monthly Labor Review, Vol. 136, No. 4, 16-23. 
Majeed, T.M. (2020). 'Evidence of Scottish trade union members' job dissatisfaction', Global Journal of Business Research, Vol. 14, No. 1.

Meng, R. (1990). 'The relationship between unions and job satisfaction', Applied Economics, Vol. 22, 1635-1648.

Miles, M.B., Huberman, A.M. and Saldana, J. (2014). Qualitative data analysis: a methods sourcebook, 3rd Ed., Sage Publications, Inc. Thousand Oaks, California.

Miller, P.W. (1990). 'Trade unions and job satisfaction', Australian Economic Papers, Vol. 29, No. 55, $226-248$.

Miller, P.M. and Mulvey, C. (1996). 'Unions, firm size and wages', Economic Record, Vol. 72, No. 217, $138-151$.

Nickell, S.J. (1977). 'Trade unions and the position of women in the industrial wage structure', British Journal of Industrial Relations, Vol. 25, No. 2, 192-210.

Odewahn, C.A. and Petty, M.M. (1980). 'A comparison of levels of job satisfaction, role stress, and personal competence between union members and non-members', Academy of Management Journal, Vol. 23, No. 1, 150-155.

Pencavel, J. (2009). 'How successful have trade unions been? A utility-based indicator of union well-being', Industrial and Labor Relations Review, Vol. 62, No. 2, 147-156.

Renaud, S. (2002). 'Rethinking the union membership/job satisfaction relationship: some empirical evidence in Canada', International Journal of Manpower, Vol. 23, No. 2, 137-150.

Rios-Avila, F., and Hirsch, B.T. (2014). 'Unions, wage gaps, and wage dispersion: new evidence from the Americas', Industrial Relations, Vol. 53, No. 1, 1-27.

Schwochau, S. (1987). 'Union effects on job attitudes', Industrial \& Labor Relations Review, Vol. 40, No. 2, $209-224$.

Simms, M. and Charlwood, A. (2010). 'Trade unions: power and influence in a changed context', In Colling, T. and Terry, M. (eds). Industrial Relations: Theory and Practice, 3rd Edition, John Wiley \& Sons, Ltd., West Sussex.

Stinglhamber, F., Gillis, C., Teixeira, C.P. and Demoulin, S. (2013). 'To be or not to be unionized? A question of organizational support and identification', Journal of Personnel Psychology, Vol. 12, No. 2, 92-96.

Sverke, M. and Goslinga, S. (2003). 'The consequences of job insecurity for employers and unions: exit, voice and loyalty', Economic and Industrial Democracy, Vol. 24, No. 2, 241-270.

Torm, N. (2014). 'The role of trade unions in Vietnam: a case study of small and medium enterprises', Journal of International Development, Vol. 26, No. 2, 207-221.

van den Berg, A. and Grout, W. (1992). 'Union membership in the Netherlands: a cross-section analysis', Empirical Economics, Vol. 17, No. 4, 537-564.

West, K.L. and Mykerezi, E. (2011). 'Teachers' unions and compensation: the impact of collective bargaining on salary schedules and performance by pay schemes', Economics of Education Review, Vol. 30, No. 1, 99-108.

Yin, R.K. (2014). Case study research: designs and methods, $5^{\text {th }}$ Ed, Sage publications, Inc. Thousand Oaks, California. 